\title{
The construction of WORK-Life BAlance: The EXPERIEnCE OF Black EMPLOYEES IN A CALL-CENTRE ENVIRONMENT
}

\author{
Authors: \\ Sónia C.B. Potgieter ${ }^{1}$ \\ Antoni Barnard ${ }^{2}$
}

Affiliations:
${ }^{1}$ Vodacom Pty (Ltd),
South Africa

${ }^{2}$ Department of Industrial and Organisational

Psychology, University of South Africa, South Africa

\section{Correspondence to:}

Antoni Barnard

email:

barnaha@unisa.ac.za

\section{Postal address:}

Department of Industrial and Organisational Psychology, University of South Africa, PO Box 392, UNISA 0003, South Africa

\section{Keywords:}

employee wellness; grounded theory; in-depth interview; qualitative research; quality of life work-home interaction

\section{Dates:}

Received: 02 Feb. 2010 Accepted: 08 June 2010

Published: 11 Aug. 2010

How to cite this article: Potgieter, S.C.B., \& Barnard, A. (2010). The construction of work-life balance: The experience of Black employees in a call-centre environment. SA Journal of Industrial Psychology/SA Tydskrif vir Bedryfsielkunde, 36(1), Art. \#892, 8 pages. DOI:10.4102/ sajip.v36i1.892

This article is available at: http://www.sajip.co.za

\section{(C) 2010. The Authors.}

Licensee: OpenJournals Publishing. This work

is licensed under the

Creative Commons

Attribution License.

\section{ABSTRACT}

Orientation: Work-life balance, as a crucial aspect of employee and organisational wellness, remains an interesting field of research, especially due to the changing demographic employee profile.

Research purpose: The objective of the study was to explore Black employees' construction of work-life balance in a customer care environment.

Motivation for the study: The conceptual debate regarding the construct of work-life balance in general as well as limited qualitative research with regard to Black employees' experience of worklife balance in a South African context motivated the study.

Research design, approach and method: This qualitative study was designed from an interpretivist perspective. Ten employees, selected through purposeful sampling, participated in the study. Data was gathered through in-depth interviews and grounded theory was applied during data analysis.

Main findings: The grounded theory analysis of the data yielded six themes central to participants' construction of work-life balance. The findings suggest that work-life balance is conceptualised as a continuous, subjective and holistic valuation of satisfaction derived from multiple roles in relation to the importance to the individual at a given point in time.

Practical/managerial implications: Findings provide valuable managerial information to guide suitable strategies enhancing the work-life balance experience and by implication employees' general wellbeing, job satisfaction and commitment.

Contributions/value-add: This study contributes to the evolving body of knowledge with regard to work-life balance and provides a unique context-specific perspective to the conceptual understanding of the construct.

\section{INTRODUCTION}

Research has shown that work and home (or family) are the two most significant domains in the life of an employed individual (Greenhaus, Collins \& Shaw, 2003; Kofodimos, 1993; Lewis \& Cooper, 1995; Papalexandris \& Kramar, 1997). International trends regarding employee and organisational wellness emphasise work-life balance (Grant-Vallone \& Donaldson, 2001; Lewis \& Cooper, 1995) and have directed a significant shift in the workplace towards work-life balance and quality of life (Parkes \& Langford, 2008; Schreuder \& Coetzee, 2006). As such, research and literature in the past decade reflect an increased interest in work-life balance issues internationally (Greenhaus et al., 2003; Kalliath \& Brough, 2008) and in work-home interaction/interface in the South African work context (Lee \& Steele, 2009; McLellan \& Uys, 2009; Mostert \& Oldfield, 2009; Van Aarde \& Mostert, 2008).

Given demographic trends in the workforce, such as more working mothers (Casale \& Posel, 2002; Patel, Govender, Paruk \& Ramgoon, 2006) and two-earner or single-earner families (Robles, 1997; Theunissen, Van Vuuren \& Visser, 2003), it is not surprising that research activity in the area of work-life balance has increased. Yet apart from different and evolving definitions of work-life balance and despite the presumed virtue thereof, the concept has not undergone extensive scrutiny (Greenhaus et al., 2003) and in fact much debate and uncertainty has been noted with regard to conceptualising and measuring the construct (Eikhof, Warhurst \& Haunschild, 2007; Heraty, Morley \& Cleveland, 2008).

According to Greenhaus et al. (2003), most of the major reviews of work-family relations either do not mention work-life balance per se, or when work-life balance is mentioned it is not explicitly defined. Furthermore, in studies where work-life balance or related constructs are explored, researchers seem to have used several different approaches to operationally define and measure the construct (Grant-Vallone \& Donaldson, 2001; Greenhaus et al., 2003). Conceptual difference is also evident in the variety of related terminology that is used to denote work-life balance, for example work-home interaction (Mostert \& Oldfield, 2009), work-life alignment (Parkes \& Langford, 2008), work-family balance (Greenhaus et al., 2003) and work-family interface (Heraty et al., 2008). In summary, Kalliath and Brough (2008) state that

while the term work-family balance is widely adopted a formal definition of this term remains elusive ... an array of definitions and measures populate the literature ... [providing] limited value for both the theoretical advancement of the construct and for practical human resource interventions.

(Kaitlan et al., 2008, pp. 323-324)

Research seems to have focussed predominantly on work-life balance issues from a gender perspective (see Patel et al., 2006); from a perspective of employees with parental care responsibilities; and from an age perspective (Eikhof et al., 2007). Relatively little focus on the unique work-life balance experiences of employees in different race groups is evident. In their study, Mostert and Oldfield (2009) specifically found significant differences in the work-home interaction amongst different socio-demographic groups (including among others age, gender, ethnicity and language) and as a result recommend further exploration of work-life balance differences in different socio-demographic groups. 
According to Brink and De la Rey (2001), South African socioeconomic, political and societal circumstances will influence employees' experiences of work-life balance differently in comparison with other countries. In South Africa, employment equity is a reality and individuals from groups that were previously disadvantaged and historically excluded have increasingly become part of the workforce and are subject to influences of westernisation, potentially transforming traditional, culture-specific family roles. In light of a review conducted by Barnett (1996), it seems that we know very little about how different resource characteristics such as race and culture shape the work-family experience. Having evidenced the impact of gender and age differences on the experience of work-life balance, it seems plausible to expect that other demographic differences may also affect the impact of work-family balance on individual wellbeing and work outcomes (cf. Grzywacz, Almeida \& McDonald, 2002; Frone, Russell \& Cooper, 1997). The call-centre work environment has furthermore been highlighted as one that has a unique impact on employees' experiences of work and consequently on their work-life balance (Hauptfleisch \& Uys, 2006; Visser \& Rothmann, 2008).

Although studies on work-life conflict and work-life balance in the South African context have increased in the past decade, research predominantly approaches work-family interaction from a quantitative perspective (e.g. Lee \& Steele, 2009; Rost \& Mostert, 2007; Van Aarde \& Mostert, 2008) and also includes certain limitations such as a predominant focus on measuring negative (as opposed to positive) work-home interference (Mostert \& Oldfield, 2009). It is worth mentioning that specific work has been done in the field of multiple roles, especially into how South African women in managerial positions integrate their multiple roles (Brink \& De la Rey, 2001; Grzywacz et al., 2002; McLellan \& Uys, 2009; Patel et al., 2006; Theunissen et al., 2003; Whitehead \& Kotze, 2003). That being said, Franks, Schurink and Fourie (2006) believe that more in-depth qualitative work involving Black South African employees, who are careerfocused and engaged in full-time work, is necessary.

\section{Research objective}

The introductory discussion highlights the conceptual differences that exist in the work-life balance research domain as well as the predominantly quantitative research perspective in this field in South Africa. This research has therefore been motivated by a general need for concept clarification of work-life balance. For consistency in executing our research, we decided to use the term 'work-life balance' as opposed to work-family interaction/ interface. In our review of contemporary literature in the field (Eikhof et al., 2007; Fleetwood, 2007; Kalliath \& Brough, 2008; Lewis, Gambles \& Rapoport, 2007; Parkes \& Langford, 2008; Poelmans, Kalliath \& Brough, 2008; Roberts, 2007), the term 'work-life balance' is used despite the fact that the meaning of the concept has been challenged. Terms such as 'workfamily balance' and 'work-home interaction/interface' seem to be preferred by organisational psychology research in the South African context (see De Klerk \& Mostert, 2010; Mostert \& Oldfield, 2009; Rost \& Mostert, 2007; Van Aarde \& Mostert, 2008) although some of these studies also refer to research in the field of 'work-life balance' (Mostert \& Oldfield, 2009; Schreuder \& Coetzee, 2006).

The unique constraints in a call-centre environment mentioned above and experienced by one of the researchers being employed as a human resources manager responsible for call-centre employees, determined the context of this study. Furthermore, the need for more in-depth qualitative work involving full-time, career-oriented Black South African employees, highlighted by Franks et al. (2006), impacted on the sample decisions made in this study.
As a result, the aim of this study was to explore the construction of work-life balance from the experience of a sample of employees classified as Black (in terms of the Employment Equity Act 55 of 1998) in a call-centre environment.

\section{Potential value-add of the study}

Theoretically, this study's findings may contribute to the evolving body of knowledge in South Africa on work-life balance from a unique perspective, bearing in mind that it is contextually specific to a sample of Black employees in a call-centre environment. The study is also significant from a methodological point of view in that work-life balance is qualitatively explored. Participants' self-awareness with regard to achieving balance may be heightened and the study may sensitise management to the motivational impact of structuring work and work hours for employees in this callcentre environment.

In what follows in this article, evolving theoretical perspectives on the concept of work-life balance are analysed in the literature review, after which the research methodology is presented. Finally the results of the study are presented and discussed.

\section{Literature review}

From the introductory discussion to this article it is clear that concept clarification of work-life balance remains a complex, yet necessary, pursuit. In qualitative research, according to both Morse (1994) and Kelly (2004), a theoretical review is, however, not only used to focus the research, but also to provide the opportunity for a critical theoretical comparison in developing conceptual outcomes, such as is intended with this study. In the following literature review, we therefore reflect on evolving perspectives on the construction of work-life balance, which have over the past decade introduced a paradigm shift to conventional perspectives thereof. As such, our analysis of the data was also influenced by both past and more recent conceptions of the construct and it is in this light that the following review of relevant conceptual literature is presented.

The interest in work-life balance originates from perspectives emphasising conflict between work and family roles, and according to Roberts (2007) overwork was initially identified as the primary reason for work-life balance problems. This perspective probably contributed to Greenhaus and Beutell's (1985) earlier opinion that work-life conflict results when mutually incompatible pressures are experienced in work and family roles. The continued interest in work-life balance issues focussed in particular on married woman entering the job market, on dual-career couples and single-parent households (see Van Aarde \& Mostert, 2008). A review of the literature reveals that earlier perspectives on work-life balance were dominated by rather negative perceptions of the impact that work has on family (Eagle, Icenogle, Maes \& Miles, 1998; Greenhaus et al., 2003; Rost \& Mostert, 2007). While some researchers began to recognise the bi-directional nature of work and family demands (Kinnunen \& Mauno, 1998), earlier studies in general focussed more on spillover effects from work to family than on family-to-work influence (Frone et al., 1997; Fu \& Shaffer, 2001).

According to Rost and Mostert (2007), the past decade has seen a renewed interest in work-life balance experiences. In general, this is again due to more demographic changes in the labour profile, but also specifically to increasing workforce diversity facilitated by legislated employment equity and affirmative action drives. However, changing paradigms about work on the one hand, and more ambiguous boundaries between work and family spheres on the other, also seem to be contributing to a change in the work-life balance research focus. 
Research focussing on the negative impact from work to home is based on negative assumptions about work and its meaning to the employee. Such negative perceptions about work and its impact on the family role lead to work-life balance interventions narrowly emphasising either a reduction in working hours or more flexible working hours (Roberts, 2007). Eikhof et al. (2007, p. 328) state that ' $[t]$ hus, premised on negative and reductionist assumptions about work, the work-life balance debate fails to capture more varied employee attitudes to and engagement with work'. Recent research calls for a changed perspective, recognising the fact that work may be a source of satisfaction and an opportunity for growth and fulfilment for people (see Eikhof $e t$ al., 2007). Inspired by the assumption that work may evoke positive feelings of competence and wellbeing, Mostert and Oldfield (2009) also recommend a stronger focus on exploring positive work-to-family interaction.

It is our opinion that the increasing ambiguity of work-life boundaries also influences work-life balance perspectives and research. Flexible working hours, information technology and working from home offices, entrepreneurial activities and other changes in the world of work have put more people in unique work-life circumstances than before; and differentiation between work and home roles has as a result become less clearly defined in terms of time and space boundaries. Such a perspective seems to be relevant to earlier perspectives on work-life balance, emphasising equality in the distribution of resources between work and family roles. Greenhaus et al. (2003), for example, defined work-life balance as the equal distribution of resources and an equally positive commitment to multiple roles. They continue to construct work-life balance as consisting of a high level of inputs (i.e. resources such as time and energy) and an equally high level of output in the form of satisfaction. The three components of work-life balance are then identified as time balance, involvement balance and satisfaction balance (Greenhaus et al., 2003).

Yet of late, work-life balance perspectives instead emphasise the fact that people experience work and life as inseparable, and intertwined; and they do not have the need to disentangle the two (Eikhof et al., 2007; Van Aarde \& Mostert, 2008). In this regard, Poelmans, Kalliath and Brough (2008) suggest that achieving harmony between life roles is a more appropriate perspective on balance. Different to the equality perspective, Kirchmeyer (2000) defines work-life balance as an experience of satisfaction in all of one's life domains, which requires personal energy, time and commitment resources well distributed across these domains (emphasis added).

Another evolvement in perspectives on work-life balance worth mentioning here is the one emphasising role salience. In a sense this is also in response to the equality debate and stems from developmental psychology. Proponents of the role salience perspective emphasise that work-life balance is related to meeting one's expectations and needs with regard to their multiple roles (Eby, Casper, Lockwood, Bordeaux \& Brinley, 2005). The fact that people differentially value their respective work and life roles in different life stages is furthermore emphasised. As such, Greenhaus and Allen (in Kalliath \& Brough, 2008) define work-life balance as the extent of compatibility between one's satisfaction in multiple roles and one's life role priorities at a given time in one's life.

In summary, the most significant shifts in perspectives of worklife balance thus seem to call for a more positive perspective to people's experience of work-life interaction and to work itself. Also implied is a more qualitative context-specific exploration of people's experiences of work-life balance due to the changing and unique experiences of work-life boundaries and of role salience.

\section{RESEARCH DESIGN}

\section{Research approach}

Assuming a relativist ontology, that is presuming that multiple realities are constructed by people as they go about life, an interpretive research paradigm was chosen in conducting a qualitative inquiry into work-life balance. A qualitative approach is epistemologically and methodologically congruent with an interpretive paradigm, as it supports the need to apply appropriate research methods to capture the richness of people's social worlds, in order to ultimately understand or appreciate it (Denzin \& Lincoln, 2003; Silverman, 2000).

\section{Research strategy}

This study employed in-depth interviews with 10 employees in a customer care environment.

\section{Research methods}

\section{Research setting and sampling}

The study was conducted in the call-centre section of the South African division of a multinational telecommunications company. In line with Marshall and Rossman (1999), who argue that a study should be conducted in a setting in which the complexity you wish to research operates, purposive sampling was used. When new themes were no longer emerging, data saturation was achieved, with 10 employees finally having participated in the data-gathering process. Small samples are appropriate to qualitative research so as to enhance rapport between the researcher and participants, and to allow an indepth interpretive exploration of the research phenomenon in a specific context. Such an in-depth contextualised approach enhances the possibility of transferring findings to similar contexts (Miles \& Huberman, 1994; Silverman, 2000).

The primary sampling parameters were race and employment. Black employees with at least five years' corporate work experience, as indicative of their full-time career focus, were sampled. Some of the 10 participants were married or partnered and some were single men and women who either had no children or had at least one child. Participants also occupied different positions and levels (grades). Table 1 provides a summary profile of the research participants at the time of data-gathering.

TABLE 1

Profile of participants

\begin{tabular}{|c|c|c|c|c|c|c|c|}
\hline Race & Gender & Age & Position & Work experience (years) & Years in customer care & Married/ partnered > 2 yrs & Children \\
\hline Coloured & M & 33 & Executive Head of Customer Care & 14 & 10 & Yes & 1 \\
\hline African & M & 41 & Manager: Business Operations Support (BOS) & 19 & 10 & Yes & 2 \\
\hline Coloured & M & 32 & Specialist & 12 & 12 & Yes & 2 \\
\hline Indian & M & 31 & Supervisor: Call-centre & 13 & 1 & Yes & None \\
\hline Indian & M & 27 & Communications Coordinator & 9 & 10 months & No & None \\
\hline Indian & $\mathrm{F}$ & 37 & Senior Specialist (BOS) & 14 & 8 & Yes & 4 \\
\hline African & $\mathrm{F}$ & 35 & Manager: Call-centre & 14 & 12 & Yes & 1 \\
\hline African & $\mathrm{F}$ & 40 & Senior Quality Assessor & 7 & 7 & No & 1 \\
\hline Coloured & $\mathrm{F}$ & 52 & Supervisor: Call-centre & 25 & 13 & Yes & 1 \\
\hline Coloured & $\mathrm{F}$ & 29 & Team Leader & 10 & 7 & Yes & 1 \\
\hline
\end{tabular}




\section{Entrèe and establishing researcher roles}

Permission was obtained from the executive director of the customer care department to conduct the study. Potential research participants were then contacted via e-mail, where the context and purpose of the study was explained and an interview with them was requested. All the contacted participants agreed to partake in the study and individual interviews were set up Researcher roles were explained during each interview.

\section{Data-gathering}

Qualitative methods of data collection (e.g. observation and interviewing) are favoured by researchers working with interpretive and constructionist paradigms (Terre Blanche \& Durrheim, 1999). For this study, the semi-structured in-depth interview (see Kvale, 1996) was used as the main method of data collection. Based on an initial review of relevant literature, an interview guide was prepared to give structure and guidance to the interview (cf. Marshall \& Rossman, 1999; Stroh, 2000). A pilot interview was conducted, after which the interview guide was adjusted to focus on eliciting core work-life balance experiences. Examples of questions asked include:

- 'Tell me about balancing your work-life with your personal life...

- 'What problems do you encounter?

- 'How would you describe work-life balance?'

- 'Tell me about your experiences of work-life balance.'

Interviews were conducted over a two-week period to gather data on participants' subjective construction of work-life balance.

\section{Recording of data}

Permission was requested to audio-tape the interviews. Digital recordings were transcribed immediately after all the interviews were concluded, as Silverman (2000) recommends that transcription happen as soon as possible to facilitate analysis. A professional transcriber was employed in this regard. Field notes and interview notes were also recorded by the researcher.

\section{Data analysis}

The grounded theory approach was used to analyse the data following the steps of open coding, axial coding and selective coding in an iterative and flexible manner (Locke, 2001; Pandit, 1996; Strauss \& Corbin, 1999). The transcribed interviews represented the main source for the open coding phase in the study. During open coding, data was fractured into smaller concepts and categories, and no conscious attempt was made to interpret the data or extract themes from the data. During axial coding, the focus was on identifying possible relationships between initially coded concepts and categories in order to develop main categories or themes from the data and their sub-categories (see Pandit, 1996). Selective coding is the process of selecting the central theme/s integrating all other inferred themes or main categories (Strauss \& Corbin, 1999). Data analysis constituted an iterative process of moving back and forth between the different coding stages; data was analysed until it had been theoretically saturated, that is, until no new themes regarding the identified concepts emerged and the relationship between the various concepts had been well established and validated.

\section{Strategies employed to ensure quality data}

Credibility and transferability of the study were enhanced by establishing an audit trail of the data (see Miles \& Huberman, 1994) through digital recording and verbatim transcriptions as well as process notes spanning data collection and data analyses. As recommended by Marshall and Rossman (1999), interpretations made in this study are consistently grounded in the raw data by providing verbatim substantiation to themes presented. Silverman (2000) also suggests that applying a particular analytical model, such as grounded theory, enhances the transferability of the findings.

Silverman (2000) explains that good research goes back to the participants with the tentative results and refines them in the light of the participants' reactions. After data analyses, member validation was done, allowing participants to reflect on their personal contributions in relation to the interpretations of the data. In addition, a peer review of the data was conducted by another researcher.

\section{Reporting}

In congruence with a more modernist, qualitative research perspective, the reporting style employed is more objective and neutral than personal and reflexive. Furthermore, in reporting on the findings, conceptual interpretations are substantiated with verbatim excerpts from the data and integrated with relevant theory as suggested by Locke (2001, p. 117), that the presentation of results should 'weave together data incidents and theoretical elements'.

\section{FINDINGS}

From the 48 themes that were initially extracted during the open coding phase, six themes central to the construction of work-life balance by participants were ultimately identified. These themes are discussed below as representing the meaning that participants attach to work-life balance. As integrity in reporting results requires a demonstration that the explanations and conclusions presented are generated from, and grounded in, the data (Ritchie \& Lewis, 2004), themes are substantiated by verbatim extracts from the data. An integration of the data with existing literature also forms part of the discussion, further confirming the relevance and integrity of interpretations made.

Theme 1: An interaction between multiple roles: As is evident in the abundant literature on work-life balance, balance becomes a problem due to potentially conflicting expectations in different work-life roles and having to divide scarce resources between specifically the work role and the family role. Participants also frequently referred to balancing the work role and the family role in particular. As an example, one participant mentions:

I do believe that you must have a balance. For me, when you are at work, you give 100 percent towards your job. When you are at home, family life for me is extremely important, extremely.

And another participant states:

I try to ensure that my life or day's life is partitioned equally and proportionately to what my work requires of me, as well as what my family also requires of me.

Mostert and Oldfield (2009) refer to work-home interaction as an interactive process of combining work and family roles and demands and in which a person's functioning in either one of these two roles impacts on the other (see also Greenhaus et al., 2003; Rost \& Mostert, 2007). Although multiple roles is clearly a factor in work-life balance (Kalliath \& Brough, 2008), Heraty et al. (2008) mention that historically research in the field was usually either from a family-focused perspective or a workfocused perspective.

In line with Parkes and Langford's (2008) as well as Lee and Steele's (2009) broader perspectives on work roles versus nonwork roles (rather than the work versus family role), participants clearly indicated the importance of the self as an additional role in the work-life balance equation. A participant explained that balance is the opportunity to do what he wants to do in a period of time that he sets - giving himself personal space or breathing time:

Balance is not just about me and the family, it is also about my own time, you know; sometimes I just need to be by myself and that is how I deal with stuff. 
The need for personal time is also reflected in the following response from another participant:

If it is too heavy on both sides, you need another outlet, and I use other outlets such as going to movies. I used to go to night clubs, still sometimes want to go, but there is no time for that, and then, ja, I go to gym or jog.

And another says: 'For me, it is make the sacrifice, but reward yourself at that particular period in time.' The general multiplicity of roles is further evident in the following:

My wife and I normally set goals for ourselves, where at the beginning of the year we open up a spreadsheet and then we will make different tabs, one for church life, one for our health, you know in terms of our gym and stuff like that, and another one for our eating, so we have different tabs and we try to stick to it.

Data thus indicates clearly that balance is not just about work and family roles. It is also about having personal and leisure time, attending to spiritual roles and other physical needs. When considering the construction of work-life balance, the findings therefore confirm the interaction between multiple roles as core to our understanding of work-life balance. Interacting with, and reflecting on, issues of the self are additionally emphasised as being crucial to the work-life balance equation, and the multiple role perspective should explicitly include the self as a key role with expectations and demands to be considered.

Theme 2: Valuing the quality of work-life dynamics: Analysis of work-life balance experiences reveals an underlying activity in which one is consistently evaluating the extent of satisfaction derived from multiple life roles. In judging their work-life balance, some participants seemed more concerned with the quality of the balance in their life, rather than with the frequency of balance. One participant explained that for him it is not about the frequency of balance, but more importantly about the quality of the balance in his life over a particular period of time:

Don't try and get balance everyday because something will happen so then you have nothing to look forward to because you are trying to do it every single day. I look at it from the quality; like I said, you know, there is a frequency how often I am going to do it, and if once a year is fine for me, it is how much I get out of that once a year as opposed to doing it every day.

Participants also explained that work-life balance should not necessarily have time boundaries; rather, it should be outcomesbased:

You shouldn't have the time boundary. A lot of projects, a lot of environments have become outcomes-based. It is like I have got to deliver on stuff, and I have got to manage my time in order to deliver it by a specific date.

International perspectives on work-life balance seem to be moving away from an overemphasis on flexible work schedules as the only solution to work-life balance issues. Eikhof et al. (2007) seriously criticise such a perspective as being grounded in the assumption that all people are more or less negative about work and need more time with their families. Time management alone and the division of time are therefore no longer adequate in defining or addressing work-life balance (Roberts, 2007). Lee and Steele (2009) note that research is moving towards the recognition of potential enrichment or facilitation amongst multiple roles, which may buffer negative work-life balance experiences. From the data it is clear that although flexibility of work hours positively contributes to work-life balance, it is rather the quality of experience in different life spheres that is of value to participants. Depending on their assessment of these quality outcomes, participants frame a positive or negative perception of the work-life balance.

Theme 3: Work-life balance is subjectively experienced: From the data it is also clear that participants' needs differ and therefore work-life balance seems to be a subjective experience, since people differentiate their balance in terms of their needs and expectations in different life roles. Some participants emphasise the importance of family over work: 'Work is not the most important; family is obviously more important to me, but work is priority'; and:

I do not think there is anything worse than your home life being upset, because if your home life is upset, nothing else works for you. You can be the greatest person in your career, you can be the best, most educated, most learned, most well-organised person at work but if you are not okay at home, believe me you are not going to perform the way you want to perform at work or the way you can perform.

Yet other participants emphasise work over family:

Sometimes I don't wish to go home; I feel like, oh, there is nothing to rush home to... Somebody would ask me, why do you stay until so late? I say there is no life at home, because I just go home and I do things my way.

If I could, I would spend more time at work than at home; it is not the workload; it is, you know, loving and having an impression of what you are doing. I always say I would rather do something that I am rewarded for. You know, you get recognition at work. I love my job; I have passion.

Contrary to the findings above, Greenhaus et al. (2003) present a very objective and inflexible perspective to work-life balance in that they suggest that balance is obtained when equal time and involvement are put into both the work and family roles and when equal satisfaction is derived from these roles. However, in more recent commentaries, Poelmans et al. (2008) and Roberts (2007) emphasise that every individual experiences work-life balance in a different way. They concur that balance is inextricably linked to satisfaction, which is a subjective phenomenon and as such argue that balance needs to be assessed as a function of a person's priorities or individual differences. Eikhof et al. (2007) cite various studies indicating different antecedents of work-life balance, which suggest that work-life balance is not an objective observation of someone else's life, but a subjective experience of the individual. The finding that work-life balance is a subjective experience also relates to the perspective that individuals perceive their multiple roles as varying in importance (salience); and therefore assessment of work-life balance will change over time in relation to one's life and career development stages (see Kalliath \& Brough, 2008; Parkes \& Langford, 2008)

Theme 4: A holistic experience of multiple role satisfaction/ fulfilment: According to Eikhof et al. (2007)

research over the years has revealed that only some workers experience work and life as separate and balanceable. For other workers, work and life are intertwined, even amalgamated, so that they cannot or do not want to distinguish and disentangle work and life.

(Eikenhof et al., 2007, pp. 325-326)

They emphasise that work-life balance perspectives need to progress to a more holistic understanding of life in which work and life are regarded as positive and enabling experiences. Similarly one participant emphasises that his work and family roles overlap:

Reasonably I cannot give 100 percent to my work. I would love to do this. If you are a family man, you cannot do that... obviously the one would overlap with the other, and you know when you start feeling the pressure coming from work; then you learn to focus more on work, and vice versa as well.

Numerous positive experiences of participants' work roles were evident in the data and confirmed the evolving perspective that work-life balance is a holistic experience of multiple roles as opposed to splitting life into multiple boxes with spillover effects from the one to the other. In stating that 'I will never look for a routine environment, you know, so if it is challenging, that is the drive that keeps me interested, keeps you on high alert', a participant emphasises that the need to work does not inhibit or replace the need to have a family. Similarly another says:

I think it all depends on an individual how you take it. If you are passionate about your work, you will give more and you will be willing to do it without any problem. 
A participant also expressed the need to grow in his career but also to have the opportunity to live out his family role. He states that he needs 'to develop and grow [in his career] and you know for me to be able to do what I need to do for them [his family] as well'.

The holistic experience of fulfilment or satisfaction is also emphasised by Lee and Steele (2009), and Kirchmeyer (in Kalliath \& Brough, 2008) describes it as achieving satisfying experiences in and across all life domains. In this regard a participant referred to work-life balance as achieving personal growth: 'I would say I view it as, you know, it contributes towards your personal growth. You grow as a person, so it is more of personal growth.' Various other literature resources also refer to satisfaction or fulfilment across multiple roles as being implicit to the work-life balance experience (Parkes \& Langford, 2008); and some also refer to personal growth as implicit in achieving balance (Kalliath \& Brough, 2008). In conclusion, our understanding of work-life balance therefore confirms that work and family roles as well as the role of self and other potential life roles are not mutually exclusive and clearly separable. Rather these roles are intertwined and as a result a person will experience work-life balance as a holistic valuation of the quality outcomes of multiple role interaction.

Theme 5: A continuous life process: Kalliath and Brough (2008) suggest that levels of work-life balance in a person's life change over time due to the differentiation of role needs and expectations linked to developmental tasks over one's life span. Such a life stage perspective is also evident in the following response:

Some people really do not have work-life balance and they have kids and things like that and it does get hard. So I think I am sitting in a better position now that I do not really have all those responsibilities yet. But I do believe when I do that work-life balance is going to be so much more important.

Kalliath and Brough (2008) agree that role salience not only varies across life and work roles, but also changes over time within those roles; and that continuous adjustment to multiple demands across at least the period of employment is a more realistic view of work-life balance. Kofidimos (in Poelmans et al., 2008) states that most people regard work-life balance as ephemeral requiring a never-ending balancing act of multiple demands, and as such Poelmans et al. (2008, p. 228) define work-life balance as 'a continuous process of creating harmony between work, family and personal life'. Finally Koekemoer and Mostert's (2006) conclusion that individuals may alternate their emphases on work and family activities in the short run to achieve balance in the long run is emphasised in the words of a participant: 'Don't try and get balance every day... it is how much I get out of that once a year as opposed to doing it every day.

Theme 6: A managing competence: Contemporary definitions of management emphasise planning (including prioritisation and scheduling). The organising of resources and control are core competencies in effective management. Various participant responses indicated that management of multiple role dynamics is essential in working towards work-life balance. Specifically role prioritisation, time management and establishing support structures (organising resources) were referred to as key activities in attempts to achieve work-life balance.

Results indicate that participants who were able to prioritise and schedule time efficiently experienced greater balance. One person explicitly said about work-life balance that it goes with planning and prioritising' and another confirmed that worklife balance is not attained by poor planning: 'I would say poor planning, because if everything was planned properly in the beginning then we would have that because you would actually be able to plan your life.' Furthermore, the need to prioritise roles appears to be influenced by the individual participants' values and goals and the varying importance they place on work and family roles. As such some participants emphasised prioritisation both between the work and family roles as well as within each role:

So it is about prioritising also, but when you also get home you need to prioritise and say, this is the family time; I have to do the family responsibilities and chores first and then get to the work thing, so it is a question of just mingling around responsibilities when you get to the other side.

I don't have a set formula that I am using. I just play it by what is more pressing or what is more urgent at the point in time and prioritise from there.

Similarly time management is an essential component of managing balance:

If I spend too much time at work, it could make things at home suffer... I have been at a point where I give more of my time to work, and you start becoming a stranger in your own home; you need to find balance.

With regard to organising resources to assist in achieving work-life balance, all of the participants identified their family support structures (mother, siblings, grandparents, in-laws) as being helpful and supportive with regard to work emergencies. Some emphasise support structures at home:

I will have a similar support structure in place at home, but not only with my immediate family, but with my second family, like for instance my mother, or fiancé's mother or my brother or my sister.

The existence and extent of support structures are instrumental in the experience of work-life balance and these include spouses, grandparents, parents, cousins and siblings (see Edwards \& Rothbard, 2000; Robles, 1997). Most participants also indicated support from an organisational perspective as resulting from a supportive manager and from supportive colleagues as summarised in the following words:

From a work perspective, the guys, they are pretty demanding, pretty tough sometimes, but they also understand family time is family time, and especially in my job, I think my boss allowed us to be very flexible. I have co-operation from my colleagues. I have co-operation from my boss and I can speak to my colleagues and without hesitations the guys will cover... The guys are very supportive and I can rely on the team.

This finding is consistent with research indicating that supervisor support reduces strain and behaviour-based workto-family conflict (Batt \& Valcour, 2003; Fu \& Shaffer, 2001) and with the study conducted by Hauptfleisch and Uys (2006): this indicates the importance of team members as a support system in work-life balance experiences.

\section{DISCUSSION}

Due to the conceptual debate in the work-life balance literature as well as limited conceptual research in the South African work context, the aim of this study was to explore the worklife balance construction of employees in a South African callcentre environment. Motivated by Franks et al. (2006), Black employees in full-time employment were sampled.

In summary, interpretation of the data produced the following six themes central to explaining work-life balance as constructed by participants in this study (and integrated with relevant theoretical perspectives on the construct):

- $\quad$ an interaction between multiple roles

- valuing the quality of work-life dynamics

- work-life balance is subjectively experienced

- a holistic experience of multiple role satisfaction/fulfilment

- a continuous life process

- a managing competence. 
In integrating these themes to produce a central theoretical perspective, we conclude the following: work-life balance for a sample of Black call-centre employees seems to be best explained by the fact that it manifests as a subjective and holistic valuation of work-life dynamics in relation to the proportionate importance the individual attaches to multiple roles. As such, work-life balance is regarded as a lifelong process of consistently evaluating the quality of multiple worklife role outcomes in relation to one another. This continuous process implies a challenge to the individual in that it entails building competence to efficiently manage the interaction between multiple roles.

From the results, it seems evident that the conceptual debate underlying work-life balance as a construct is substantiated. Traditional perspectives regarding work-life balance based on employees' experiences of work and family as separate entities, and in which work has a predominantly negative impact on the family, were not evident in the data. Work-life balance seems rather to be the result of acknowledging multiple roles in life (not just work and family) and that satisfaction in all life roles contributes to the experience of balance. Furthermore balance seems to be subjectively judged by each individual - a judgement that is influenced by each particular life stage, which again determines the importance of various life roles in relation to one another. Based on these findings, using the term 'work-life balance' may no longer be appropriate as the construct in itself implies a dichotomous nature between work and life. In contradiction, participants clearly indicated that their lives incorporate work as a very important role impacting positively on their experience of balance. As such, we believe that referring to work/non-work balance (see Lee \& Steele, 2009) may constitute a more appropriate conceptualisation of employees' holistic experience of balance in their lives.

The study contributes to the evolving conceptual understanding of work-life balance in a changing world of work, bearing in mind that it provides a context-specific perspective to the conceptual understanding thereof due to the sample parameters. Still, similarities between the results and conceptual reviews provide some evidence that traditional work-life balance perspectives are changing, and should be incorporated in future explorations of the work and non-work dynamics. The results of this study further provide potentially practical and valuable information to organisational leaders and human resource managers in a call-centre environment. Insights gained can facilitate implementing suitable strategies to enhance work/non-work balance experiences and as such garner employees' general wellbeing, job satisfaction and commitment. Finally, the study was found to be valuable by participants in that it increased their self-awareness regarding work/non-work balance and as such lead to the generation of alternative solutions to manage the challenges they face in integrating their multiple roles.

\section{Limitations}

It is not our intention to claim that the approach followed here will deliver a final solution to conceptual problems related to work-life balance, but rather that it would contribute to the current body of research with the aim of working towards a sound and contextually grounded definition of the construct. In this regard some limitations also impacted on the study. As the study was restricted to a specific working environment (call-centre) and the participants differed in terms of age, race, marital status and years of work experience, its findings cannot necessarily be transferred to other work contexts. Furthermore, the impact of having a white female interviewer on participants' responses may have manifested unconsciously during data-gathering and data analysis. Similar potential bias may have resulted from the fact that the interviewer is a colleague of many of the participants. Such potential bias was addressed through submitting the results for peer review and member validation.

\section{Recommendations for future research}

Although the findings cannot be transferred to other work environments, they prove meaningful for the purpose of this study. Research replicating the present study in different organisational contexts will also help to enhance our understanding of unique work/non-work balance experiences and facilitate the development and implementation of more appropriate balance policies and strategies in the 20th century world of work. Longitudinal studies would furthermore add significant insight to understanding an individual's subjective experiences of work/non-work balance over time.

\section{REFERENCES}

Barnett, R.C. (1996). Toward a review of work-family literature: Work in progress. Boston: Wellesley College Center for Research on Women.

Batt, R., \& Valcour, P.M. (2003). Human resources practices as predictors of work-family outcomes and employee turnover. Industrial Relations, 42(2), 189-220.

Brink, B., \& De la Rey, C. (2001). Work-family interaction strain: coping strategies used by successful women in the public, corporate and self-employed sectors of the economy. South African Journal of Psychology, 31(4), 55-61.

Casale, D., \& Posel, D. (2002). The continued feminisation of the labour force in South African: An analysis of recent data and trends. The South African Journal of Economics, 70(1), $156-184$.

De Klerk, M., \& Mostert, K. (2010). Work-home interference: Examining socio-demographic predictors in the South African context. SA Journal of Human Resource Management, $8(1), 1-10$.

Denzin, N.K., \& Lincoln, Y.S. (2003). The landscape of qualitative research: Theories and issues. (2nd edn.). London: Sage Publications.

Eagle, B.W., Icenogle, M.L., Maes, J.D., \& Miles, E.W. (1998). The importance of employee demographic profiles for understanding experiences of work-family interrole conflicts. The Journal of Social Psychology, 138(6), 690-709.

Eby, L.T., Casper, W.J., Lockwood, A., Bordeaux, C., \& Brinley, A. (2005). Work and family research in IO/OB: Content analysis and review of the literature (1980-2002). Journal of Vocational Behaviour, 66(1), 124-197.

Edwards, J.R., \& Rothbard, N.P. (2000). Mechanisms linking work and family: Clarifying the relationship between work and family constructs. Academy of Management Review, 25(1), 178-199.

Eikhof, D.R., Warhurst, C., \& Haunschild, A. (2007). What work? What life? What balance? Critical reflections on the work-life balance debate. Employee Relations, 29(4), 325-333.

Fleetwood, S. (2007). Re-thinking work-life balance: Editor's introduction. International Journal of Human Resource Management, 18(3), 351-359.

Franks, K., Schurink, W., \& Fourie, L. (2006). Exploring the social construction of life roles of career-orientated women. $S A$ Journal of Industrial Psychology, 32(1), 17-24.

Frone, A.R., Russell, M., \& Cooper, M.L. (1997). Relation of workfamily conflict to health outcomes: A four-year longitudinal study of employed parents. Journal of Occupational and Organizational Psychology, 70(4), 325-335.

Fu, C.K., \& Shaffer, M.A. (2001). The tug of work and family. Personnel Review, 30(5), 214-226.

Grant-Vallone, E.J., \& Donaldson, S.I. (2001). Consequences of work-family conflict on employee well-being over time. Work and Stress, 15(3), 214-226.

Greenhaus, J.H., Collins, K.M., \& Shaw, J.D. (2003). The relation between work-family balance and quality of life. Journal of Vocational Behavior, 63(3), 510-531.

Greenhaus, J.H., \& Beutell, N.J. (1985). Sources of conflict between work and family roles. Academy of Management Review, 10(1), 76-88. 
Grzywacz, J.G., Almeida, D.M., \& McDonald, D.A. (2002) Work-family spillover and daily reports of work and family stress in the adult labor force. Family Relations, 51(1), 28-36.

Hauptfleisch, S., \& Uys, J.S., (2006). The experience of work in a call-centre environment. South African Journal of Industrial Psychology, 32(2), 23-30.

Heraty, N., Morley, M.J., \& Cleveland, J.N. (2008). Complexities and challenges in the work-family interface. Journal of Managerial Psychology, 23(3), 209-214.

Kalliath, T., \& Brough, P. (2008). Work-life balance: A review of the meaning of the balance construct. Journal of Management $\mathcal{E}$ Organization, 14(3), 323-327.

Kelly, K. (2004). Hermeneutics in action: Empathy and interpretation in qualitative research. In M. Terre Blanche, \& K. Durrheim (Ed.), Research in practice: Applied methods for the social sciences. Cape Town: University of Cape Town Press.

Kinnunen, U., \& Mauno, S. (1998). Antecedents and outcomes of work-family conflict among employed women and men in Finland. Human Relations, 51(2), 157-176.

Kirchmeyer, C. (2000). Work-life initiatives: Greed or benevolence regarding workers' time. In C.L. Cooper and D.M. Rousseau (Eds.), Trends in organisational behaviour (pp. 79-93). Chichester: John Wiley \& Sons.

Koekemoer, F.E., \& Mostert, K. (2006). Job characteristics, burnout and negative work-home interference in a nursing environment. SA Journal of Industrial Psychology, 32(3), 87-97.

Kofodimos, J.R. (1993). Balancing act. San Francisco: JosseyBass.

Kvale, S. (1996). Interviews: An introduction to qualitative research interviewing. Thousand Oaks: Sage.

Lee, G.J., \& Steele, C.L. (2009). Boundary management of employees' non-work lives: Effects on South African workers' commitment. South African Journal of Economic and Management Sciences, 12(1), 63-80.

Lewis, S., \& Cooper, C.L. (1995). Balancing the work/home interface: A European perspective. Human Resource Management Review, 5(4), 289-305.

Lewis, S., Gambles, R. \& Rapoport, R. (2007). The constraints of a 'work-life balance' approach: An international perspective. International Journal of Human Resource Management, 18(3), $360-373$.

Locke, K. (2001). Grounded theory in management research. London: Sage Publications.

Marshall, C., \& Rossman, G.B.(1999). Designing qualitativeresearch. (3rd edn.). London: Sage Publications.

McLellan, K., \& Uys, K. (2009). Balancing dual roles in selfemployed women: An exploratory study. South African Journal of Industrial Psychology, 35(1), 21-30.

Miles, M.B., \& Huberman, A.M. (1994). Qualitative data analysis: An expanded source book. (2nd ed.). London: Sage Publications.

Morse, J.M. (1994). Designing funded qualitative research. In N.K. Denzin \& Y.S. Lincoln (Ed.), Handbook of qualitative research. Thousand Oaks: Sage.

Mostert, K., \& Oldfield, G.R. (2009). Work-home interaction of employees in the mining industry. South African Journal of Economic and Management Sciences, 12(1), 81-99.
Pandit, N.R. (1996, December). The creation of theory: A recent application of the grounded theory method. The Qualitative Report, 2(4). Retrieved September 19, 2009 from http://www. nova.edu/sss/QR/QR2-4/pandit.html

Parkes, L.P., \& Langford, P.H. (2008). Work-life balance or worklife alignment. Journal of Management $\mathcal{E}$ Organization, 14(3), 267-283.

Papalexandris, N., \& Kramar, R. (1997). Flexible working patterns: Towards reconciliation of family and work. Employee Relations, 19(6), 581-595.

Patel, C.J., Govender, V., Paruk, Z., \& Ramgoon, S. (2006). Working mothers: Family-work conflict, job performance and family/work variables. SA Journal of Industrial Psychology, 32(2), 39-45.

Poelmans, S.A.Y., Kalliath, T., \& Brough, P. (2008). Achieving work-life balance: Current theoretical and practice issues. Journal of Management $\mathcal{E}$ Organizations, 14(3), 227-238.

Republic of South Africa. (1998). Employment Equity Act 55 of 1998. Pretoria: Government Printers.

Ritchie, J., \& Lewis, J. (2004). Qualitative research practice: A guide for social science students and researchers. London: Sage Publications.

Roberts, K. (2007). Work-life balance: The sources of the contemporary problem and the probable outcomes. Employee Relations, 29(4), 334-351.

Robles, B.J. (1997). An economic profile of women in the United States. In E. Higginbotham \& M. Romero (Ed.), Women and work: Exploring race, ethnicity and class (pp. 5-27). Thousand Oaks: Sage.

Rost, I., \& Mostert, K. (2007). The interaction between work and home of employees in the earthmoving equipment industry: Measurement and prevalence. SA Journal of Industrial Psychology, 33(2), 54-61.

Schreuder, A.M.G., \& Coetzee, M. (2006). Careers: An organisational perspective. (3rd edn.). Pretoria: Juta \& Co. Ltd.

Silverman, D. (2000). Doing qualitative research: A practical handbook. London: Sage Publications.

Strauss, A.L., \& Corbin, J. (1999). Basics of qualitative research: Techniques and procedures for developing grounded theory. (2nd ed.). London: Sage Publications.

Stroh, M. (2000). Qualitative interviewing. In Burton, D. (Ed.), Research training for social scientists. London: Sage Publications.

Terre Blanche, M., \& Durrheim, K. (1999). Research in practice: Applied methods for social sciences. Cape Town: University of Cape Town Press.

Theunissen, B., Van Vuuren, L.J., \& Visser, D. (2003) Communication of job-related information and workfamily conflict in dual-career couples. South African Journal of Industrial Psychology, 29(1), 18-25.

Van Aarde, A., \& Mostert, K. (2008). Work-home interaction of working females: What is the role of job and home characteristics? South African Journal for Industrial Psychology, 34(3), 1-10.

Visser, W.A., \& Rothmann, S. (2008). Exploring antecedents and consequences of burnout in a call-centre. South African Journal for Industrial Psychology, 34(2), 79-87.

Whitehead, T., \& Kotze, M.E. (2003). Career and life-balance of professional women: A South African study. SA Journal of Human Resource Management, 1(3), 77-84. 